\title{
Memaknai Pentingnya Perawatan Kesehatan Masyarakat Dalam Meningkatkan Kualitas
} Hidup

\author{
Dwi Sogi Sri Redjeki \\ Universitas Sari Mulia, Banjarmasin \\ rinacubby72@gmail.com
}

DOI: $10.33859 / \mathrm{dksm.v11i1.624}$

\begin{abstract}
Abstrak
Latar belakang: Pembangunan perawatan kesehatan merupakan bentuk aktivitas dalam rangka mengisi kemerdekaan bangsa supaya dapat mewujudkan masyarakat yang sehat dan kuat. Salah satunya adalah dengan melakukan penyelenggaraan pelayanan kesehatan. Pelayanan kesehatan adalah sebuah kegiatan yang diberikan kepada individu maupun masyarakat oleh pemerintah dengan tujuan untuk mencegah dan menyembuhkan penyakit individu maupun masyarakat.

Tujuan: Perawatan kesehatan masyarakat mengacu pada kemampuan untuk: a) membuat dan memelihara hubungan dengan orang lain; b) berinteraksi dengan baik dengan orang-orang dan lingkungan, sehingga dengan pemahaman kesehatan tersebut dapat menunjukkan kemampuan untuk beradaptasi dengan lingkungan yang berubah serta bertujuan memberikan pemaknaan sebagai kemampuan seseorang untuk berpikir secara konkrit, obyektif dalam norma dan kepatutan yang layak dalam sebuah atau suatu sistem (misal: keluarga, atau masyarakat) dalam rangka untuk merespons secara adaptif terhadap berbagai tantangan lingkungan.

Metode: Penulisan ilmiah ini dilakukan dengan melakukan analisa akademik dari aspek berbagai sumber rujukan relevan sehingga menemukan makna teoritis baru dalam rangka menjawab tantangan perawatan kesehatan yang terjadi di masyarakat.

Hasil: Paradigma perawatan kesehatan masyarakat merupakan suatu strategi baru pembangunan kesehatan yang memandang masalah kesehatan sebagai suatu variable kontinyu, direncanakan dalam suatu sistem desentralisasi, dengan kegiatan pelayanan yang senantiasa bersifat promotif untuk mengentaskan kesehatan masyarkat, oleh tenaga kesehatan professional bersama masyarakat yang partisipatif.

Kata kunci: perawatgan kesehatan, kesehatan masyarakat, hidup sehat
\end{abstract}




\section{Abstract}

Background: Health care development is a form of activity in order to fill the nation's independence which has a role to create a healthy and strong society. One of them is by conducting health services. Health service is an activity provided to individuals and communities by the government with the aim of preventing and curing individual and community diseases.

Purpose: Public health care refers to the ability to: a) make and maintain relationships with others; b) interacts well with people and the environment, so that understanding of health can demonstrate the ability to adapt to a changing environment and aims to provide meaning as a person's ability to think concretely, objectively in appropriate norms and appropriateness in a system or system (e.g. family, or community) in order to respond adaptively to various environmental challenges.

Method: This scientific paper is carried out by conducting academic analysis from various aspects of relevant reference sources so as to find new theoretical meaning in order to answer the challenges of health care that occur in society.

Results: The public health paradigm is a new health development strategy that views health issues as a continuous variable, planned in a decentralized system, with service activities that are always promotive to alleviate public health, by professional health workers together with participatory communities.

Keywords: health care, public health, healthy living

\section{Pendahuluan}

Kesehatan merupakan investasi untuk mendukung pembangunan ekonomi serta memiliki peran penting dalam upaya penanggulangan kemiskinan. Pembangunan perawatan kesehatan harus dipandang sebagai suatu investasi untuk meningkatkan kualitas sumber daya manusia. Dengan demikian maka sistem pelayanan kesehatan merupakan bagian penting dalam meningkatkan derajat kesehatan. Melalui sistem ini tujuan pembangunan kesehatan dapat tercapai dengan cara efektif, efisien dan tepat sasaran. Keberhasilan sistem pelayanan kesehatan tergantung dari berbagai komponen yang masuk dalam pelayanan diantara perawat dokter atau tim kesehatan lain yang satu dengan yang lain saling menunjang. Sistem ini akan memberikan kualitas pelayanan kesehatan yang efektif dengan melihat nilainilai yang ada di masyarakat.

Pembangunan perawatan kesehatan merupakan bentuk aktivitas dalam rangka mengisi kemerdekaan bangsa supaya dapat 
mewujudkan masyarakat yang sehat dan kuat.

Salah satunya adalah dengan melakukan penyelenggaraan pelayanan kesehatan.

Pelayanan kesehatan adalah sebuah kegiatan yang diberikan kepada individu maupun masyarakat oleh pemerintah dengan tujuan untuk mencegah dan menyembuhkan penyakit individu maupun masyarakat.

Pelayanan kesehatan dapat berbentuk pelayanan individu yang dilakukan oleh dokter praktik maupun pelayanan kesehatan yang dilakukan oleh sebuah organisasi. Semua jenis pelayanan kesehatan tersebut pada umumnya mempunyai tujuan yang sama yaitu memberikan pelayanan untuk menyembuhkan penyakit dan memulihkan kesehatan perseorangan maupun masyarakat.

Pokok pembangunan kesehatan adalah peningkatan kemampuan masyarakat untuk hidup sehat dan mengatasi sendiri masalah kesehatan sederhana terutama melalui upaya peningkatan, pencegahan dan penyembuhan. Perpres RI No 72 Tahun 2012 Pasal 1 ayat (2) menyebutkan bahwa "Sistem Kesehatan Nasional, yang selanjutnya disingkat SKN adalah pengelolaan kesehatan yang diselenggarakan oleh semua komponen bangsa Indonesia secara terpadu dan saling mendukung guna menjamin tercapainya derajat kesehatan masyarakat yang setinggitingginya”.

Pelayanan kesehatan masyarakat adalah sub sistem pelayanan kesehatan yang tujuan utamanya adalah pelayanan preventif (pencegahan), promotif (peningkatan kesehatan), kuratif dan rehabilitatif dengan sasaran masyarakat. Fasilitas pelayanan kesehatan adalah suatu alat dan/atau tempat yang digunakan untuk menyelenggarakan upaya pelayanan kesehatan, baik promotif, preventif, kuratif maupun rehabilitatif yang dilakukan oleh Pemerintah, Pemerintah daerah, dan/atau masyarakat.

Dalam aspek manajemen pembangunan kesehatan, dengan diterapkannya desentralisasi kesehatan, permasalahan yang dihadapi adalah kurangnya sinkronisasi kegiatan antara Pusat dan Daerah, peningkatan kapasitas SDM daerah terutama dalam perencanaan, peningkatan sistem informasi, terbatasnya pemahaman terhadap peraturan 
perundangan serta struktur organisasi

kesehatan yang tidak konsisten.

\section{Makna Komunitas Perawatan Kesehatan}

Didefinisikan secara luas, komunitas adalah kumpulan orang yang berinteraksi satu sama lain dan yang kepentingan atau karakteristiknya memberi mereka rasa persatuan dan kepemilikan. Komunitas adalah sekelompok orang di area geografis yang ditentukan dengan tujuan dan sasaran yang sama dan potensi untuk berinteraksi. satu sama lain dalam suasanan yang saling melengkapi.

Fungsi komunitas mana pun termasuk pentingnya rasa memiliki dan adanya identitas bersama dalam pemaknaan: nilai, norma, komunikasi, dan perilaku pendukung anggotanya. Beberapa komunitas pada umumnya terdapat beberapa kondisi seperti antara lain: a) komunitas yang mungkin berbagi hampir semua hal; dan b) komunitas lain (besar, tersebar dan terdiri dari individu) yang mungkin hanya berbagi minat yang sama dan keterlibatan dalam tujuan tertentu.

Demikian pula, suatu komunitas sering didefinisikan oleh batas geografisnya dan oleh karenanya disebut komunitas geografis, contoh adalah kota. Kota atau lingkungan adalah komunitas geografis. Komunitas yang dibatasi oleh batas geografis menjadi target yang jelas untuk analisis kebutuhan kesehatan untuk menjadi dasar perencanaan program kesehatan dan komunitas geografis juga mudah dimobilisasi untuk bertindak (Hermino, 2019).

Komunitas juga dapat diidentifikasi dengan minat atau tujuan bersama. Sekumpulan orang, meskipun mereka tersebar luas secara geografis, dapat memiliki minat atau tujuan yang mengikat anggota-bersamasama disebut komunitas kepentingan bersama. (misal, penyandang cacat yang tersebar di luar kota besar dapat muncul sebagai komunitas melalui kepentingan bersama dalam kebutuhan mereka akan akses yang lebih baik untuk kursi roda atau fasilitas cacat lainnya).

Komunitas memiliki tiga fitur: lokasi, populasi, dan sistem sosial. Pertama, lokasi: setiap komunitas fisik melakukan keberadaannya sehari-hari di lokasi geografis tertentu. Kesehatan komunitas dipengaruhi oleh lokasi ini, termasuk penempatan layanan, fitur geografis. Kedua, Populasi: terdiri dari 
agregat khusus, tetapi semua orang yang

berbeda yang hidup dengan batas komunitas.

Ketiga, sistem sosial: berbagai bagian sistem

sosial masyarakat yang berinteraksi dan

mencakup sistem kesehatan, sistem keluarga, sistem ekonomi, dan sistem pendidikan.

\section{Makna Perawatan Kesehatan}

Perawatan Kesehatan didefinisikan

sebagai keadaan kesejahteraan fisik, mental dan sosial bukan hanya tidak adanya penyakit atau kelemahan (Hermino, 2019). Kesehatan, dalam filosofi holistiknya sangat berbeda dari pengaturan perawatan akut. Kesehatan fisik menyiratkan fungsi mekanistik tubuh. Kesehatan mental berarti kemampuan untuk berpikir jernih dan koheren dan ada hubungannya dengan pemikiran dan perasaan seseorang dan bagaimana seseorang tersebut menangani masalah yang dihadapi. Seseorang yang sehat secara mental memiliki kapasitas untuk hidup bersama orang lain, untuk memahami kebutuhan mereka, dan untuk mencapai hubungan yang saling memuaskan.

Perawatan Kesehatan sosial mengacu pada kemampuan untuk: a) membuat dan memelihara hubungan dengan orang lain; b) berinteraksi dengan baik dengan orang-orang dan lingkungan. Kesehatan dapat menunjukkan kemampuan untuk beradaptasi dengan lingkungan yang berubah untuk tumbuh dan menua, untuk penyembuhan ketika rusak, untuk penderitaan dan untuk harapan kematian yang damai. Demikian pula kesehatan dapat dimaknai sebagai kemampuan seseorang berpikir secara konkrit, obyektif dalam norma dan kepatutan yang layak dalam sebuah atau suatu sistem (misal: keluarga, atau masyarakat) dalam rangka untuk merespons secara adaptif terhadap berbagai tantangan lingkungan.

Kesehatan juga dapat dipandang sebagai sebaliknya dari penyakit sebagai tidak ada penyakit. Lebih jauh, kematian tidak dipandang sebagai penyakit pamungkas tetapi sebagai bagian alami dari pertumbuhan dan perkembangan (Coleman \& Garfield, 2004). Dengan demikian maka dapat dianggap bahwa interaksi individu dengan ekologi sebagai pengaruh penting pada kesehatan dan penyakit. Kesehatan juga dikonseptualisasikan sebagai sumber kehidupan sehari-hari. Ini 
adalah ide positif yang menekankan sumber daya sosial dan pribadi dan kemampuan fisik.

Setiap orang memiliki persepsi pribadi terhadap kesehatan. Beberapa orang menggambarkan kondisi kesehatan mereka baik meskipun sebenarnya mereka mungkin memiliki satu atau lebih penyakit yang didiagnosis. Itu karena setiap orang merasakan kesehatan dalam kaitannya dengan harapan dan nilai-nilai pribadi. Konsep kesehatan harus memungkinkan adanya variabilitas individual. Kesehatan adalah keadaan dinamis di mana orang tersebut secara konstan beradaptasi dengan perubahan dalam lingkungan internal dan eksternal, misalnya seseorang dapat melihat dirinya sehat saat mengalami infeksi pernapasan.

Kesehatan adalah gaya hidup yang bertujuan untuk mencapai kesejahteraan fisik, emosional, intelektual, spiritual, dan lingkungan. Penggunaan langkah-langkah kesehatan dapat meningkatkan stamina, energi, dan harga diri, kemudian meningkatkan kualitas hidup. Konsep kesehatan juga memungkinkan adanya variabilitas individu. Kesehatan dapat dianggap sebagai keseimbangan aspek fisik, emosional, psikologis, sosial dan spiritual dari kehidupan seseorang. Ini adalah keadaan yang dinamis. Setiap orang akan mendefinisikan kesehatan dalam kaitannya dengan harapan pribadi. Perilaku kesehatan adalah perilaku yang mendorong fungsi yang sehat dan membantu mencegah penyakit. Ini termasuk, misalnya, manajemen stres, kesadaran gizi, dan kebugaran fisik.

Ada berbagai model konsep kesehatan. Beberapa model didasarkan secara sempit pada ada atau tidak adanya penyakit yang dapat didefinisikan. Lainnya didasarkan lebih konseptual pada kepercayaan kesehatan, kesejahteraan dan holisme. Kesehatan diartikan sebagai tidak adanya tanda dan gejala penyakit atau cedera; dengan demikian kebalikan dari kesehatan adalah penyakit. Makna kesehatan sebagai keadaan relatif bebas dari penyakit, dan kondisi homeostasis relatif. Karena itu, penyakit adalah sesuatu yang terjadi pada seseorang. Banyak penyedia layanan kesehatan fokus pada kepercayaan tanda dan gejala penyakit dan menyimpulkan bahwa ketika ini tidak ada lagi, orang tersebut 
sehat. Terhadap hal ini kondisi tersebut mungkin tidak mempertimbangkan kepercayaan kesehatan seseorang atau gaya hidup seseorang (Hermino, 2016).

\section{Model Lingkungan untuk Perwatan}

\section{Kesehatan}

Model ini membantu mengidentifikasi penyebab suatu penyakit. Dalam model ini, terdapat tiga makna yang perlu dicermati, yaitu: a) tuan rumah: mengacu pada orang (atau kelompok) yang mungkin berisiko atau rentan terhadap suatu penyakit; b) agen: adalah faktor apa pun (internal atau eksternal) yang dapat menyebabkan penyakit dengan kehadirannya; dan c) lingkungan: merujuk pada faktor-faktor tersebut (fisik, sosial, ekonomi, emosional, spiritual) yang dapat menciptakan kemungkinan atau kecenderungan bagi orang tersebut untuk terserang penyakit.

Dalam model lingkungan untuk kesehatan dan penanganan kesehatan, terdapat hubungan antara keyakinan dan tindakan seseorang. Faktor-faktor yang mempengaruhi keyakinan seseorang tersebut, seperti: a) harapan pribadi dalam kaitannya dengan kesehatan dan penyakit; b) pengalaman sebelumnya dengan penyakit atau kesehatan; serta c) usia dan status perkembangan. Untuk mencapai keyakinan kesehatan tersebut maka diperlukan komitmen dalam diri seseorang untuk hidup sehat. Keyakinan kesehatan adalah sebuah gagasan, dan sikap seseorang tentang kesehatan dan penyakit. Terhadap hal ini pemahaman seseorang mungkin didasarkan pada informasi faktual, informasi yang salah, akal sehat atau mitos, atau kenyataan atau harapan yang salah, sehingga kepercayaan kesehatan biasanya mempengaruhi perilaku kesehatan, pengaruh ini bisa positif atau negatif.

Model Kesehatan Kepercayaan atau Health Belief Model (HBM), model ini memberikan pemaknaan berkenaan dengan adanya kehidupan sehari-hari terhadap kualitas hidup, dimana: a) kepercayaan dapat berkontribusi dalam mengatasi hubungan antara keyakinan dan perilaku orang; b) kepercayaan kesehatan dapat memberikan cara untuk memahami dan memprediksi bagaimana klien akan berperilaku sehubungan dengan 
Dinamika Kesehatan Jurnal Kebidanan dan Keperawatan Vol 11 No. 1 Juli 2020 ( ISSN: 2086-3454 EISSN: 2549-4058)

url: http://ojs.dinamikakesehatan.unism.ac.id DOI : https://doi.org/10.33859/dksm.v11i1

Memaknai Pentingnya Perawatan Kesehatan Masyarakat Dalam Meningkatkan Kualitas Hidup

kesehatan mereka dan bagaimana mereka akan

mematuhi terapi perawatan kesehatan.

Komponen dalam HBM, antara lain: a)

komponen pertama, yaitu persepsi individu.

Persepsi individu tentang kerentanan terhadap

penyakit; b) komponen kedua, yaitu faktor

memodifikasi. Persepsi individu tentang

keseriusan penyakit. Persepsi ini dipengaruhi

dan dimodifikasi oleh variabel demografis dan

sosial-psikologis, ancaman penyakit yang

dirasakan dan isyarat untuk bertindak; c)

komponen ketiga (kemungkinan aksi), yaitu

kemungkinan bahwa seseorang akan

mengambil tindakan pencegahan timbul dari

persepsi orang tersebut tentang manfaat dan

hambatan untuk mengambil tindakan.

Tindakan pencegahan dapat meliputi:

modifikasi/perubahan gaya hidup, peningkatan

kepatuhan terhadap terapi medis atau mencari

saran atau perawatan medis.

Berdasarkan pemaknaan diatas maka implikasi HBM untuk kesehatan masyarakat adalah dalam rangka berkenaan membantu masyarakat untuk memahami faktor-faktor yang mempengaruhi klien terhadap: a)

persepsi; b) keyakinan dan perilaku; c) merencanakan kesehatan yang paling efektif

dalam menjaga atau memulihkan kesehatan dan mencegah penyakit, sehingga kesehatan diakui sebagai proses yang berkelanjutan menuju fungsi potensial tertinggi seseorang. Proses ini melibatkan orang, keluarga, dan komunitas. Terhadap hal ini kesehatan dicerminkan sebagai pengalaman orang yang hidup dengan cahaya kesehatan yang baik, hidup dengan gaya kesehatan yang baik dengan energi untuk dikembangkan dengan sangat baik (Hermino, 2019; Kozier, 1995).

\section{Model Kesehatan Holistik dalam Praktek Perawatan Kesehatan Masyarakat}

Holisme berasal dari kata Yunani yaitu holos yang berarti keseluruhan. Holisme dipandang sebagai model kesehatan baru yang mengikuti perkembangan jaman, tetapi sebenarnya itu bukan hal baru sama sekali. Holisme telah menjadi tema utama dalam humaniora, tradisi politik dan pembiasaan hidup di sepanjang sejarah. Holisme adalah pendekatan yang berbeda untuk kesehatan yaitu mengakui dan menghormati interaksi pikiran, tubuh, dan jiwa seseorang dalam lingkungan. 
Dinamika Kesehatan Jurnal Kebidanan dan Keperawatan Vol 11 No. 1 Juli 2020 ( ISSN: 2086-3454 EISSN: 2549-4058)

url: http://ojs.dinamikakesehatan.unism.ac.id DOI : https://doi.org/10.33859/dksm.v11i1

Memaknai Pentingnya Perawatan Kesehatan Masyarakat Dalam Meningkatkan Kualitas Hidup

\section{Holisme dipandang pula sebagai}

penangkal bagi pendekatan otomatisasi sains

kontemporer. Suatu pendekatan otomatisasi yang memisahkan beberapa hal-hal, seperti memeriksa susuatu sepotong demi sepotong dalam upaya untuk memahami gambaran yang lebih besar dengan memeriksa molekul atau atom yang lebih kecil (Hermino, 2014).

Holisme didasarkan pada kepercayaan bahwa orang-orang (atau bahkan bagianbagian mereka) tidak dapat sepenuhnya dipahami jika diperiksa hanya dalam bagianbagian yang terpisah dari lingkungan mereka. Orang dipandang sebagai sebuah sistem energi yang berubah.

Praktek perawatan kesehatan masyarakat merupakan bagian dari upaya kesehatan masyarakat yang lebih besar yang berkaitan dengan pelestarian dan peningkatan kesehatan populasi dan komunitas tertentu. Praktik kesehatan masyarakat menggabungkan enam elemen dasar: yaitu pertama, promosi kesehatan: a) hal ini mencakup semua upaya yang berusaha mendekatkan orang untuk kesejahteraan optimal atau tingkat kesehatan yang lebih tinggi; b) ini adalah kombinasi dari dukungan pendidikan dan lingkungan untuk tindakan dan kondisi kehidupan yang kondusif bagi kesehatan. Kedua, pencegahan masalah kesehatan, hal ini menyangkut upaya pemberian pemahaman kepada masyarakat khususnya berkenaan dengan kesehatan lingkungan, kesehatan dalam keluarga, dan kesehatan untuk diri sendiri. Kondisi ini tentunya sangat berpengaruh pada tingkat pendidikan pada seseorang maupun masyarakat. Ketiga, pengobatan kelainan: a) fokus pada akhir penyakit dari kontinum dan merupakan aspek perbaikan dari praktik kesehatan masyarakat. Hal ini dipraktikkan melalui: (i) layanan langsung kepada orangorang dengan masalah kesehatan, misalnya kunjungan rumah untuk orang lanjut usia, penyakit kronis, dll; (ii) layanan tidak langsung, misalnya membantu orang-orang dengan masalah kesehatan untuk mendapatkan perawatan dan rujukan; (iii) pengembangan program untuk memperbaiki kondisi yang tidak sehat; misalnya alkoholisme, penyalahgunaan narkoba. Keempat, rehabilitasi. Hal ini melibatkan upaya-upaya yang berupaya mengurangi disabilitas, 
sebanyak mungkin, dan memulihkan fungsi; misalnya rehabilitasi stroke. Kelima, Evaluasi.

Hal ini adalah proses di mana praktik dianalisis, dinilai, dan ditingkatkan sesuai dengan tujuan dan standar yang ditetapkan. Ini membantu untuk memecahkan masalah dan memberikan arahan untuk perencanaan perawatan kesehatan di masa depan. Keenam, penelitian. Hal ini adalah penyelidikan sistematis yang membantu menemukan fakta yang memengaruhi kesehatan masyarakat dan praktik kesehatan masyarakat, menyelesaikan masalah, dan mengeksplorasi metode peningkatan layanan kesehatan.

\section{Perawatan Kesehatan Masyarakat}

Perawatan kesehatan masyarakat dapat didefinisikan sebagai sintesis keperawatan dan praktik kesehatan masyarakat yang diterapkan untuk mempromosikan dan melindungi kesehatan populasi. Ini adalah bidang keperawatan khusus yang berfokus pada kebutuhan kesehatan masyarakat, kelompok agregasi, dan khususnya populasi rentan. Ini adalah praktik yang berkelanjutan dan komprehensif yang ditujukan kepada semua kelompok anggota masyarakat. Ini menggabungkan semua elemen dasar keperawatan klinis, profesional dengan kesehatan masyarakat dan praktik masyarakat. Terdapat setidaknya enam karakteristik keperawatan kesehatan masyarakat yang patut dicermati, yaitu: 1) bidang keperawatan khusus; 2) praktik penggabungan kesehatan masyarakat dengan keperawatan; 3) fokus pada populasi; 4) penekanan pada kesehatan dan penyakit; 5) pelibatan kolaborasi antardisiplin; 6) promosi tanggung jawab dan perawatan diri klien. Perawatan kesehatan masyarakat berlangsung dalam berbagai pengaturan yang meliputi peningkatan kesehatan, pencegahan penyakit, pemeliharaan kesehatan, pemulihan, koordinasi, manajemen dan evaluasi perawatan individu, keluarga, dan kelompok agregat, termasuk masyarakat. Dalam pengaturan komunitas, perawatan berfokus pada memaksimalkan potensi individu untuk perawatan diri terlepas dari cedera atau penyakit apapun. Perubahan dalam layanan perawatan kesehatan menghasilkan perubahan dalam perawatan juga. Pengaturan diubah ke komunitas dan terutama ke rumah. Maksud perawatan bukan untuk memperbaiki 
Dinamika Kesehatan Jurnal Kebidanan dan Keperawatan Vol 11 No. 1 Juli 2020 ( ISSN: 2086-3454 EISSN: 2549-4058)

url: http://ojs.dinamikakesehatan.unism.ac.id DOI : https://doi.org/10.33859/dksm.v11i1

Memaknai Pentingnya Perawatan Kesehatan Masyarakat Dalam Meningkatkan Kualitas Hidup

dengan perawatan tetapi untuk meningkatkan

kualitas hidup dan mendukung tindakan yang membuat hidup klien senyaman mungkin.

Dengan demikian dapat dimaknai bahwa perawatan kesehatan masyarakat adalah seni dan ilmu untuk memperpanjang hidup, mempromosikan kesehatan dan mencegah penyakit melalui organisasi upaya masyarakat.

Keperawatan kesehatan masyarakat mengacu pada komposisi layanan keperawatan dan promosi kesehatan populasi. Hal ini bertujuan untuk: 1) meningkatkan sanitasi; 2) kontrol epidemi masyarakat; 3) mencegah penularan infeksi; 4) memberikan pendidikan tentang prinsip-prinsip dasar kebersihan pribadi; 5) mengatur layanan medis dan keperawatan untuk diagnosis dini, pencegahan dan pengobatan penyakit.

Peningkatan kesehatan tidak dilihat sebagai hasil dari jumlah dan jenis layanan medis atau ukuran rumah sakit. Perawatan yang diberikan dalam pengaturan perawatan akut biasanya diarahkan untuk menyelesaikan masalah kesehatan langsung. Di masyarakat, perawatan berfokus pada memaksimalkan potensi individu untuk perawatan diri terlepas dari cedera atau penyakit apa pun. Klien memikul tanggung jawab untuk keputusan perawatan kesehatan dan penyediaan perawatan. Di mana kesehatan adalah inti dari perawatan, kemampuan klien untuk berfungsi menjadi perhatian utama.

Program berbasis pendidikan dan komunitas dapat dirancang untuk mengatasi gaya hidup (Hermino, 2016). Strategi perlindungan kesehatan terkait dengan langkah-langkah lingkungan atau peraturan yang memberikan perlindungan pada kelompok populasi besar. Perlindungan kesehatan melibatkan fokus masyarakat luas. Layanan pencegahan termasuk konseling, skrining, imunisasi, atau intervensi kemoprofilaksis untuk individu dalam pengaturan klinis. Dengan demikian maka dapat dimaknai pula bahwa fokus pencegahan adalah konsep kunci keperawatan berbasis masyarakat. Pencegahan dikonseptualisasikan pada tiga tingkatan: a) tingkat pencegahan primer; b) tingkat pencegahan sekunder; c) tingkat pencegahan tersier.

Berkanaan dengan hal ini pula maka perlu adanya kontinum kesehatan, yaitu 
perbandingan visual dari kesehatan yang

meselaraskan pada pemahaman perkembangan

jaman dengan pandangan kesehatan tradisional

tentang kesehatan. Pada makna tersebut maka

seseorang akan mengevaluasi tingkah laku hidupnya pada saat tertentu, belajar tentang pilihan yang tersedia, dan tumbuh menuju aktualisasi diri dengan mengikat keluar dari pilihan yang ada untuk mendapatkan kesehatan sesuai dengan perkembangan jaman.

\section{Strategi Paradigma Perawatan Kesehatan}

Paradigma berkembang sebagai hasil sintesa dalam kesadaran manusia terhadap informasi-informasi yang diperoleh baik dari pengalaman ataupun dari penelitian (Hermino, 2016; Hermino, 2015). Dalam perkembangan kebijaksanaan pembangunan kesehatan dalam memasuki era global untuk Indonesia telah terjadi perubahan pola pikirdan konsep dasar strategi pembangunan kesehatan dalam bentuk paradigma sehat. Sebelumnya pembangunan kesehatan cenderung menggunakan paradigma sakit dengan menekankan upaya-upaya pengobatan (kuratif) terhadap masyarakat Indonesia.
Perubahan paradigma kesehatan dan pengalaman kita dalam menangani masalah kesehatan di waktu yang lalu, memaksa kita untuk melihat kembali prioritas dan penekanan program dalam upaya meningkatkan kesehatan penduduk yang akan menjadi pelaku utama dan mempertahankan kesinambungan pembangunan. Untuk membentuk manusia Indonesia menjadi sumber daya manusia sehatproduktif-kreatif, kita harus berfikir dan agak berbeda dengan apa yang kita lakukan sekarang. Kita perlu re-orientasi dalam strategi dan pendekatan. Perubahan paradigma dan reorientasi mendasar yang perlu dilakukan adalah paradigma atau konsep yang semula menekankan pada penyembuhan penyakit berupa pengobatan dan meringankan beban penyakit diubah ke arah upaya peningkatan kesehatan dari sebagian besar masyarakat yang belum jatuh sakit agar bias lebih berkontribusi dalam pembangunan.

Perubahan paradigma kesehatan yang kini lebih menekankan pada upaya promotifpreventif dbandingkan dengn upaua kuratif dan rehabilitatif diharapkan merupakan titik balik kebijakan pemerintah dalam menangni 
kesehatan penduduk yang berarti program

kesehatan yang menitik beratkan pada

pembinaan kesehatan bangsa bukan sekedar penyembuhan penyakit. Dengan demikian maka setiap terobosan baru perlu didahului dengan perubahan paradigma untuk merubah kebiasaan dan cara berpikir yang lama. Upaya kesehatan di masa dating harus mampu menciptakan dan menghasilkan SDM Indonesia yang sehat produktif sehingga obsesi upaya kesehatan harus dapat mengantarkan setiap penduduk memiliki status kesehatan yang cukup.

Perubahan paradigma kesehatan apabila dilaksanakan dapat membawa dampak yang cukup luas (Hermino, 2014; Panggabean, 2002; Notoatmojo, 2007). Hal itu disebabkan karena pengorganisasian upaya kesehaan yang ada, fasilitas pelayanan kesehatan yang ada, adalah merupakan wahana dan sarana pendukung dari penyelenggaraan pelayanan kesehatan yang berorientasi pada upaya penyembuhan penyakit, maka untuk mendukung terselenggaranya paradigma sehat yang berorientasi pada upaya promotifpreventif proaktif, community centered, partisipasi aktif dan pemberdayaan masyarakat, maka semua wahana tenaga dan sarana yang ada sekarang perlu dilakukan penyesuaian atau bahkan reformasi termasuk reformasi kegiatan dan program di pusat penyuluhan kesehatan.

Tenaga kesehatan harus mampu mengajak, memotifasi dan memberdayakan masyarakat, mampu melibatkan kerjasama lintas sektoral, mampu mengelola system pelayanan kesehatan yang efisien dan efektif, mampu menjadi pemimpin, pelopor, pembinan dan teladan hidup sehat. Dalam pembinaan dan pemberdayaan mayarkat yang sangat penting adalah bagaimana mengajak dan menggairahkan masyarakat untuk dapat tertarik dan bertanggungjawab atas kesehatan mereka sendiri dengan memobilisasi sumber dana yang ada pada mereka.

\section{Strategi dan Sasaran Utama Pembangunan}

\section{Kesehatan}

Pembangunan kesehatan merupakan bagian yang tidak terpisahkan dari pembangunan nasional yang diupayakan oleh pemerintah. Dalam melaksanakan pembangunan kesehatan di tengah beban dan 
permasalahan kesehatan yang semakin pelik, dibutuhkan strategi jitu untuk menghadapinya.

Dalam mengatasi masalah kesehatan dapat digunakan beberapa strategi utama, antara lain:

1. Menggerakkan dan memberdayakan masyarakat untuk hidup sehat. Sasaran utama strategi ini adalah seluruh desa menjadi desa siaga, seluruh masyarakat berperilaku hidup bersih dan sehat serta seluruh keluarga sadar gizi.

2. Meningkatkan akses masyarakat tehadap pelayanan kesehatan yang berkualitas. Sasaran utama strategi ini adalah setiap orang miskin mendapatkan pelayanan kesehatan yang bermutu; setipa bayi, anak, dan kelompok masyarakat risiko tinggi terlindungi dari penyakit; di setiap desa tersedia SDM kesehatan yang kompeten; di setiap desa tersedia cukup obat esensial dan alat kesehatan dasar; setiap Puskesmas dan jaringannya dapat menjangkau dan dijangkau seluruh masyarakat di wilayah kerjanya; pelayanan kesehatan di setiap rumah sakit, Puskesmas dan jaringannya memenuhi standar mutu.
3. Meningkatkan sistem surveillans, monitoring dan informasi kesehatan. Sasaran utama dari strategi ini adalah setiap kejadian penyakit terlaporkan secara cepat kepada desa/lurah untuk kemudian diteruskan ke instansi kesehatan terdekat; setiap kejadian luar biasa (KLB) dan wabah penyakit tertanggulangi secara cepat dan tepat sehingga tidak menimbulkan dampak kesehatan masyarakat; semua ketersediaan farmasi, makanan dan perbekalan kesehatan memenuhi syarat; terkendalinya pencemaran lingkungan sesuai dengan standar kesehatan; dan berfungsinya sistem informasi kesehatan yang evidence based di seluruh Indonesia.

4. Meningkatkan pembiayaan kesehatan. Sasaran utama dari strategi ini adalah pembangunan kesehatan memperoleh prioritas penganggaran pemerintah pusat dan daerah; anggaran kesehatan pemerintah diutamakan untuk upaya pencegahan dan promosi kesehatan; dan terciptanya sistem jaminan pembiayaan kesehatan terutama bagi rakyat miskin. 
Semua kebijakan pembangunan nasional yang sedang dan/atau akan diselenggarakan harus memiliki wawasan kesehatan, artinya program pembangunan nasional tersebut harus memberikan kontribusi yang positif terhadap kesehatan, setidak-tidaknya terhadap dua hal. Pertama, terhadap pembentukkan lingkungan sehat. Kedua, terhadap pembentukkan peilaku sehat. Dengan memaknai kedua hal tersebut maka amat diharapkan setiap program pembangunan yang diselenggarakan di Indonesia dapat memberikan kontribusi yang positif terhadap terbentuknya lingkungan dan perilaku sehat tersebut. Sedangkan secara mikro, semua kebijakan pembangunan kesehatan yang sedang dan atau akan diselenggarakan harus dapat makin mendorong meningkatnya derajat kesehatan seluruh anggota masyarakat. Jika diketahui pemeliharaan dan peningkatan kesehatan tersebut akan lebih efektif dan efisien jika dilaksanakn melalui upaya promotif dan preventif, bukan upaya kuratif dan rehabilitatif, maka seyogyanyalah kedua pelayanan yang pertaama tersebut dapat lebih diutamakan. Untuk terselengggaranya pembangunan berwawasan kesehatan perlu dilaksanankan kegiatan sosialisasi, orientasi, kampanye dan pelatihan sehingga semua pihak yang terkait (stakeholders) memahami dan mampu melaksanakan pembangunan nasional berwawasan kesehatan. Selain itu, perlu pula dilakukan kegiatan penjabaran lebih lanjut dari konsep tersebut sehingga benar benar menjadi operasional serta terukur segala pencapaian dan dampak yang dihasilkan.

Profesionalisme dilaksanakan melalui penerapan kemajuan ilmu dan teknologi, serta melalui penerapan nilai-nilai moral dan etika (Panggabean, 2002; Hermino, 2015). Untuk terselenggaranya pelayanan yang bermutu, perlu didukung oleh penerapan pelbagaikemajuan ilmu dan teknologi kedokteran. Untukterwujudnya pelayanan kesehatan yang seperti ini, jelaslah pengembangan sumber daya manusia kesehatan dipandang mempunyai peranan yang amat penting. Pelayanan kesehatan profesional tidak akan terwujud apabila tidak didukung oleh tenaga pelaksana, yakni sumber daya manusia kesehatan yang mengikuti perkembangan ilmu dan teknologi. Lebih dari 
Dinamika Kesehatan Jurnal Kebidanan dan Keperawatan Vol 11 No. 1 Juli 2020 ( ISSN: 2086-3454 EISSN: 2549-4058)

url: http://ojs.dinamikakesehatan.unism.ac.id DOI : https://doi.org/10.33859/dksm.v11i1

Memaknai Pentingnya Perawatan Kesehatan Masyarakat Dalam Meningkatkan Kualitas Hidup

itu, untuk terselenggaranya pelayanan

kesehatanyang bermutu, perlu pula didukung

oleh penerapan nilau-nilai moral dan etika

profesi yang tinggi. Untuk terwujudnya

pelayanan kesehatan yang seperti ini, semua

tenaga kesehatan dituntut untuk selalu

menjunjung tinggi sumpah dan kode etik

profesi. Pelaksanaan perilaku yang dituntut

dari tenaga kesehatan seperti diatas perlu

dipantau secara berkala melalui kerjasama dengan pelbagai organisasi profesi (Hermino,

2016). Untuk terselenggaranya strategi

profesionalisme akan dilaksanakan penentuan

standar kompetensi bagi tenaga kesehatan,

pelatihan berdasarkan kompetensi, akreditasi

dan legislasi tenaga kesehatan, serta kegiatan

peningkatan kualitas lainnya. Untuk

memantapkan kemandirian masyarakat dalam

pola hidup sehat, perlu digalang peran serta

masyarakat yang seluas-luasnya, termasuk

peran serta dalam pembiayaan.

Untuk keberhasilan pembangunan

kesehatan, penyelenggaraan pelbagai upaya

kesehatan harus berangkat dari masalah dan

potensi spesifik masing-masing daerah.

Desentralisasi yang inti pokoknya adalah pendelegasian wewenang yang lebihbesar kepada pemerintah daerah untuk mengatur sistem pemerintahan dan rumah tangga sendiri memang dipandang lebih sesuai untuk pengelolaan pelbagai pembangunan nasional pada masa mendatang. Tentu saja untuk keberhasilan desentralisasi ini berbagai persiapan perlu dilakukan, termasuk yang terpenting adalah persiapan perangkat organisasi serta sumber daya manusianya. Untuk terselenggarnya desentralisasi akan dilakukan kegiatan analisa dan penentuan peran pemerintah pusat dan daerah dalam bidang kesehatan, penentuan kegiatan upaya kesehatan yang wajib dilaksanakan oleh daerah, analisa kemampuan daerah, pengembangan sumber daya manusia daerah, pelatihan, penempatan kembali tenaga dan lain-lain kegiatan sehingga strategi desentralisasi dapat terlaksana secara nyata.

Dengan demikian maka sasaran pembangunan kesehatan di Indonesia diarahkan untuk mendukung peningkatan derajat kesehatan masyarakat melalui peningkatan akses masyarakat, terutama penduduk miskin, terhadap pelayanan 
kesehatan yang antara lain tercermin pada beberapa indikator, sebagai berikut:

1) meningkatnya proporsi keluarga yang berperilaku hidup bersih dan sehat; 2) meningkatnya proporsi keluarga yang memiliki akses terhadap sanitasi dan air bersih; 3) meningkatnya cakupan persalinan yang ditolong oleh tenaga kesehatan terlatih; 4) meningkatnya cakupan pelayanan antenatal, postnatal dan neonatal; 5) meningkatnya tingkat kunjungan (visit rate) penduduk miskin ke Puskesmas; 6) meningkatnya tingkat kunjungan (visit rate) penduduk miskin ke rumah sakit; 7) meningkatnya cakupan imunisasi.

\section{Kesimpulan}

Paradigma sehat merupakan suatu strategi baru pembangunan kesehatan yang memandang masalah kesehatan sebagai suatu variable kontinyu, direncanakan dalam suatu sistem desentralisasi, dengan kegiatan pelayanan yang senantiasa bersifat promotif untuk mengentaskan kesehatan masyarkat, oleh tenaga kesehatan professional bersama masyarakat yang partisipatif.
Selain itu, dalam paradigma sehat ini pengukuran derajat kesehatan masyarakat tidak semata-mata dilihat dari penurunan kesakitan/kematian (dengan memakai indicator negatif), tetapi lebih ditekankan pada pencapaian hasil peningkatan pada angka kesehatan (indicator positif). Nilai indicator positif ini diperoleh sebagai dampak dari upaya kesehatan promotif yang telah dilaksanakan oleh tenaga kesehatan professional dan didukung besarnya penempatan biaya upaya promotif yang sesuai.

Paradigma sehat mempunyai orientasi dimana upaya peningkatan kesehatan masyarakat dititik beratkan pada: 1) berpihak pada rakyat, yaitu diperolehnya derajat kesehatan yang setinggi-tingginya bagi setiap orang adalah salah satu hak asasi manusia tanpa membedakan suku, golongan agama, dan status sosial ekonomi; 2) bertindak cepat dan tepat, yaitu dalam mengatasi masalah kesehatan, apalagi yang bersifat darurat harus dilakukan secara cepat. Tindakan yang cepat juga harus diikuti dengan pertimbangan yang cermat, sehingga dapat mengenai sasaran dengan intervensi yang tepat; 3 ) kerjasama tim, 
Dinamika Kesehatan Jurnal Kebidanan dan Keperawatan Vol 11 No. 1 Juli 2020 ( ISSN: 2086-3454 EISSN: 2549-4058)

url: http://ojs.dinamikakesehatan.unism.ac.id DOI : https://doi.org/10.33859/dksm.v11i1

Memaknai Pentingnya Perawatan Kesehatan Masyarakat Dalam Meningkatkan Kualitas Hidup

yaitu dalam mengemban tugas-tugas

pembangunan kesehatan, harus dibina kerja tim yang utuh dan kompak, dengan menerapkan prinsip koordinasi, integrasi, sinkronisasi dan sinergisme; 4) integritas tinggi, yaitu dalam melakasanakan kehidupan sehari-hari harus memiliki ketulusan hati, kejujuran, berkepribadian yang teguh, dan bermroral tinggi; dan 5) transparan dan akuntabilitas,yaitu semua kegiatan pembangunan $\quad$ kesehatan $\quad$ yang diselenggarakaan oleh pemerintah harus dilaksanakan secara transparan dan dapat dipertanggungjawabkan kepada publik.

\section{Daftar Pustaka}

Coleman WL, Garfield C. 2004. Fathers and Pediatricians: Enhancing men's roles in the care and development of their children. Psychosocial Aspects of Child and Family Health. 113 (5): 1406-1411. http://www.pediatrics.org/cgi/content/fu 11/113/5/1406.

Hermino, A. 2019. Komunitas Masyarakat dan Perawatan Kesehatan dalam Peningkatan Kualitas Hidup. Jurnal Dinamika Kesehatan. Universitas Sari Mulia. Vol. 10, No. 1. https://ojs.dinamikakesehatan.unism.ac.i d/index.php/dksm/article/view/437. DOI: https://doi.org/10.33859/dksm.v10 i1.437

Hermino, A. 2016. ASEAN Economic Community in the Pespective of
Transformational Leadership in School. International Journal of Education and Research. Vol. 4, No. 6. 401-416. http://www.ijern.com/June-2016.php

Hermino, A. 2015. Pendidikan Karakter dalam Perspektif Psikologis Siswa Sekolah Menengah Pertama di Era Globalisasi dan Multikultural. Jurnal Peradaban. Universiti of Malaya. Vol. 8. 19-40. DOI: https://doi.org/10.22452/PERADABAN .vol8nol.2

Hermino, A. 2014. Kepemimpinan Pendidikan di Era Globalisasi. Yogyakarta: Pustaka Pelajar

Kozier. 1995. Fundamental of Nursing: Concept, Process and Practice. $4^{\text {th }}$ Edition. Philadelpia: WB Saunders Company.

Notoatmojo, S. 2007. Kesehatan Masyarakat, Ilmu dan Seni. Jakarta: Rineka Cipta.

Panggabean, M.S. 2002. Manajemen Sumber Daya Manusia. Jakarta: Ghalia Indonesia. 